\title{
FINANCIAL LITERACY AND IMPACT ON WELFARE OF CHILLI FARMERS IN EAST JAVA PROVINCE INDONESIA
}

\section{WAHIB ABDUL MUHAIMIN, DWI RETNONINGSIH \& HERY TOIBA}

Research Scholar, Department of Social-Economics, Faculty of Agriculture,

University of Brawijaya, Malang, Indonesia

\begin{abstract}
This study provides empirical evidence on the factors that affect the level of financial literacy and financial literacy impact of the adoption credit and the welfare of farmers viewed from the income they generated. Two districts were chosen as a test site such as Malang and Kediri. A total of 300 farmers used as samples were analyzed by logit regression analysis and propensity score matching (PSM). The results showed participation in farmers' group is the most influential variable positive and significant impact on the level of financial literacy education followed and the number of family members. On the other hand, the life of a significant Negative effect on the level of financial literacy. Furthermore, financial literacy has a significant impact on the income of farmers, where farmers with high levels of financial literacy have higher incomes than farmers with low levels of financial literacy. This implies that financial literacy is indispensable to carry out agricultural activities.
\end{abstract}

KEYWORDS: Financial Literacy, Logit, PSM, Revenue

Received: Jun 09, 2020; Accepted: Jun 29, 2020; Published: Jul 28, 2020; Paper Id.: IJMPERDJUN2020501

\section{INTRODUCTION}

\subsection{Preliminary}

The importance of financial literacy to the attention of various parties, including government, companies and households. Due to the good financial literacy, one can make the right decision in the financial aspect (Jang et al., 2014) lack of knowledge about financial concepts in the Asian resulting in low levels of financial literacy (Grohmann, 2018). The survey results of the Financial Services Authority (FSA), (2018) only $31 \%$ of Indonesian people understand financial literacy. Therefore, should the effort to improve the level of financial literacy, so that it can be a means to improve household welfare (Huston, 2010) one of the efforts to increase financial literacy is to conduct training to those who have the financial literacy is low (Bayrakdaroğlu \& San, 2014), Rising levels of financial literacy someone will have an impact on the level of their economy,. Along with that Huston (2010) reveals that financial literacy has proved able to cope with financial problems, especially financial problems often faced by many workers. This is caused by a lack of financial literacy that resulted in them can not regulate financial flows (Lusardi, 2011). On the other hand Hakim et al, (2017) proved that the high level of financial literacy in a company manager was positively correlated with the company productivity. can be concluded that financial literacy is one positive aspect in the success of a person or company to boost their economies.

One of the causes of failure in farming is bad management of the financial aspects. This is due to the low level of financial literacy of the farmer. The important proof of financial literacy on the business activities described by Carman \& Zamarro (2016) where the household businesses with higher financial literacy have higher incomes as well. The study of financial literacy and its impact on earnings have been carried out one of Carman 
and Zammaro (2016) contribution to earnings financial literacy and food security. The results showed that financial literacy of households with high incomes and higher food security, this is because households with high financial literacy can set the financial aspects as possible. Mabula \& Dong (2018) examined the relationship between financial literacy and access to financial institutions. The results showed that financial literacy has a positive and significant relationship between financial literacy and access to finance. The institutions can be concluded that financial literacy has a positive impact on the adoption of credit and income.

Nonetheless, the study of financial literacy and its impact on revenue and adoption of credit have been carried out. But they assess financial literacy in general. That is still a bit of literature that examines financial literacy focused on farmers, particularly in Indonesia. This study tried to assess the impact of financial literacy and its impact on farmers' income.

\subsection{Financial Literacy Level Measurement}

Financial literacy is the ability of a person based on financial aspects. To measure financial literacy can be done to provide some questions related to financial concepts. This technique is most often used by researchers to measure the level of financial literacy. Some questions that are frequently used by the researchers can be seen in Table 1.

Table 1: Financial Literacy Question

\begin{tabular}{|c|c|c|}
\hline Concept & Question & Source \\
\hline $\begin{array}{l}\text { Numerac } \\
\mathrm{y}(\mathrm{Q} 1)\end{array}$ & $\begin{array}{c}\text { "Suppose you had \$ } 100 \text { in a savings account and the interest rate was } 2 \% \text { per year. } \\
\text { After } 5 \text { years, how much do you think you would have in the account if you left the } \\
\text { money to grow? (I) More than } \$ 102 \text {; (Ii) Exactly } \$ 102 ; \text { (Iii) Less than } \$ 102 ; \text { (Iv) } \\
\text { Do not know (DK); (V) Refuse. " }\end{array}$ & $\begin{array}{c}\text { Lusardi and } \\
\text { Mitchell (2007) }\end{array}$ \\
\hline $\begin{array}{l}\text { Understa } \\
\text { nding of } \\
\text { interest } \\
\text { compoun } \\
\text { ding } \\
(\mathrm{Q} 2) \\
\end{array}$ & $\begin{array}{c}\text { "Suppose you had \$ } 100 \text { in a savings account and the interest rate is } 20 \% \text { per year } \\
\text { and you never withdraw money or interest payments. After } 5 \text { years, how much } \\
\text { would you have in total on this account? (I) More than \$200; (Ii) Exactly \$200; (Iii) } \\
\text { Less than \$200; (Iv) DK; (V) Refuse." }\end{array}$ & $\begin{array}{c}\text { Lusardi and } \\
\text { Mitchell (2007) }\end{array}$ \\
\hline $\begin{array}{l}\text { Understa } \\
\text { nding of } \\
\text { inflation } \\
\text { (Q3) }\end{array}$ & $\begin{array}{l}\text { "Imagine that the interest rate on your savings account was } 1 \% \text { per year and inflation } \\
\text { was } 2 \% \text { per year. After } 1 \text { year, how much would you be able to buy with the money } \\
\text { in this account? (I) More than today; (Ii) the same; (Iii) Less than today; (Iv) DK; } \\
\text { (V) Refuse. " }\end{array}$ & $\begin{array}{c}\text { Lusardi and } \\
\text { Mitchell (2007) }\end{array}$ \\
\hline $\begin{array}{l}\text { Time } \\
\text { Value of } \\
\text { Money } \\
\text { (Q4) }\end{array}$ & $\begin{array}{l}\text { "Assume a friend inherits } \$ 10,000 \text { today and his sibling inherits } \$ 10,000 \text { three } \\
\text { years from now. Who is richer because of the inheritance? (I) My friend; (Ii) His } \\
\text { sibling; (Iii) They are equally rich; (Iv) DK; (V) Refuse. " }\end{array}$ & $\begin{array}{c}\text { Lusardi and } \\
\text { Mitchell (2007) }\end{array}$ \\
\hline $\begin{array}{l}\text { Money } \\
\text { Illusion } \\
\text { (Q5) }\end{array}$ & $\begin{array}{l}\text { "Suppose that in the year 2010, your income has doubled and the prices of all goods } \\
\text { have doubled too. In 2010, how much will you be able to buy with your income? (I) } \\
\text { More than today; (Ii) The same; (Iii) Less than today; (Iv) DK; (V) Refuse. " }\end{array}$ & $\begin{array}{c}\text { Lusardi and } \\
\text { Mitchell (2007) }\end{array}$ \\
\hline
\end{tabular}

\subsection{Theoretical Model}

\section{- Propensity Score Matching}

Problems often arise when evaluating the effects of treatments that a bias problem heterogeneity between the treatment and non-treatment. One method that can overcome the problems of such bias is propensity score matching (PSM). PSM is a statistical method to estimate match how big the effects of treatment. PSM can be used to eliminate bias due to variable existing confounding of estimating the impact of treatment derived from a simple comparison between the outcomes of respondents who get treatments and non-treatments. This method tries to evaluate the effect of covariate treatment groups was observed that the difference in the propensity score or a single index(Khandker et al., 2009). Then the outcome of the group and the non-treatment sametreatments will be compared to derive the value of the impact of treatment. While 
respondents do not have a mismatch covariate will be issued.

According to Rosenbaum and Rubin (1983), he propensity score is the conditional probability for the receiving treatment based on the characteristics before the intervention. Mathematically the propensity score as the following equation:

$$
P(Z)=P \tau\{D=1 \mid Z\}=E\{D \mid Z\}(8)
$$

Where $\mathrm{D}=(0,1)$ is a binary variable that describes the different groups, $\mathrm{D}=1$ indicates a group treatments, and $\mathrm{D}$ $=0$ is a group of non-treatments. While $\mathrm{Z}$ is an indicator before intervention treatments. The conditional distribution of $\mathrm{Z}$, at $\mathrm{p}(\mathrm{X})$ is the same for both groups of treatments or non-treatments.

Step-by-step method using propensity score matching (PSM) according to Shahidur (2010) as follows:

- Estimation of the propensity score. Estimate using propensity score using logistic regression models. The variables used to estimate the propensity score treatments is that variable as the dependent variable $(\mathrm{y})$ and household characteristics as the independent variable (x). Mathematically the logistic model can be written as follows:

$y=\alpha+\beta 1 x 1+\beta 2 x 2+\ldots \ldots \ldots \ldots i x i+e$

- Specifies the matching method (Matching algorithm). There are four methods to do the Matching algorithm. Among other nearest neighbour matching, radius matching, Kernel matching, and stratification matching.

- Identivikasi overlap and common support. In this step is matching characteristics between respondents and nontreatments treatments. So they will know some of the respondents who do not have a match, some of the respondents who have a match are respondent would do a comparison, while respondents who do not have a match that respondents with a propensity score that is too high or too low will be dropped.

- Calculating Average Effect of Treatment for the Treated (ATT). ATT calculation performed to obtain the value of the effects of treatment. The value of the ATT is the difference in the average value outcomes as between groups of treatments and non-treatments. In mathematic can be written as follows:

$$
\begin{aligned}
& \tau=E\left\{R_{1}-R_{0} \mid I=1\right\} \\
& =E\left\{E\left\{R_{1}-R_{0} \mid I=1, p(Z)\right\}\right\} \\
& =E\left\{E\left\{R_{1} \mid I=1, p(Z)\right\}-E\left\{R_{0} \mid I=0, p(Z 0\} I=0\right\}\right.
\end{aligned}
$$

\section{METHODS}

\subsection{Sample and Data}

The respondents are the head of household farmers and household heads in the partner district, Malang and Kediri.Determination of the farmer respondents is done by using simple random sampling method. The first step, will dilist all horticultural farmers in four villages of the two districts, then list horticultural farmers gained from this first step, then used to construct a sampling frame of the study. The next step, of the list of farmers who obtained, will subsequently be selected by random 75 farmer respondents from each village so overall we will get 300 respondents horticultural farmers. 


\section{DATA ANALYSIS METHOD}

\subsection{Analysis of Factors Affecting Financial Literacy}

Analysis to determine the factors that influence financial literacy using logit regression. In this analysis the dependent variable is financial literacy, while the independent variables are socio demographics. Logit regression models in this study as follows:

$$
L k=\alpha+\beta 1 x 1+\beta 2 x 2+\beta 3 x 3+\beta 4 x 4+\beta 5 x 5+\beta 6 x 6+\beta 7 x 7+e
$$

Financial literacy variables $(\mathrm{Lk})$ as the dependent variable $(1=$ high literacy and low literacy 0$)$ is $0-100$, while the independent variables consisted of gender (x1), age (x2), education (x3), the number of family members (x4), land area (x5), the status of land ownership (x6), farmer membership (x7).

\subsection{Impact Analysis of Financial Literacy to Kesejteraan Farmers}

Data analysis methods will be used to analyze the impact of financial literacy on the adoption credit is propensity score matching (PSM). This method is used to evaluate the impact of the financial literacy levels of the income of farmers. PSM method chosen because this method can reduce the problem of impact evaluation that selection bias problems caused by the counter-factual that were not observed. This bias can be reduced when the results of a comparison group of non-group treatments and treatments are as close as possible. PSM method aims to find a match of characteristics between the treatment and non-treatment.

There are three categories of variables used in this method include variable PSM treatments, the characteristics of the farmers and the outcome variable. Variable treatments in this study is the level of financial literacy that will be categorized into katogori tingtat low and high categories. While karektristik household consists ofgender, age, education, number of family members, land, land tenure, membership farmer. One final outcome variable, namely the income of farmers.

\subsection{Impact Analysis of Financial Literacy on the Adoption Credit}

Analysis of the data to determine the effect of the influence of socio-demographic variables and level of financial literacy of farmers to credit that the decision to adopt the IV probit regression. Probit regression model equation in this study as follows:

$$
\operatorname{Adp}=\alpha+\beta 1 \times 1+\beta 2 \times 2+\beta 3 \times 3+\beta 4 \times 4+\beta 5 \times 5+\beta 6 \times 6+\beta 7 \times 7+\beta 8 z 1+e
$$

In the above probit regression model is the adoption Adp credit as the dependent variable. The dependent variable in the probit regression analysis is dekotomi, which means a value of 0 describes the farmers who did not do the adoption credit and the value of 1 represents the farmers are adopting credit. While the independent variables in this study consisted of gender (x1), age (x2), education (x3), the number of family members (x4), land area (x5), the status of land ownership (x6), the membership of farmers (x7) and financial literacy level (z1). The main independent variable in this study is the level of financial literacy (z1), this variable has a value of 1-100 (shaped score) that describes how the percentage of answers to farmers about the correct financial literacy.

Endogeneity issues have been discussed in the literature review chapter. The main variables in the study of financial literacy endogeneity could potentially happen because it has the potential relationship with e thus have consequences probit MLE estimation model to be biased and is considered ineffective. To prove to these problems, it is necessary to test the endogeneity wald-test. If the test results obtained wald-test proved H0 is rejected, then the main variable in this study indicated endogeneity. 
Overcome the above problems it is necessary to add a fourth special treatment that was not correlated with e. But has a strong influence on key variables, namely financial literacy. Variable IV (q) used in this study are those costs incurred to obtain financial education and math skills during school. IV probit models in this study can be written as follows:

$$
\begin{aligned}
& \text { Adp }=\alpha+\beta 1 \times 1+\beta 2 \times 2+\beta 3 \times 3+\beta 4 x 4+\beta 5 \times 5+\beta 6 \times 6+\beta 7 \times 7+\beta 8 z 1+e \\
& z 1=y+y 1 q 1+y 2 q 2+u
\end{aligned}
$$

\section{RESULTS AND DISCUSSIONS}

\subsection{Descriptive Statistics}

In these discussions will be explained about the data based on the average, standard deviation, minimum and maximum of the value of each household characteristics. Standard deviation indicates the value that is used to see how the distribution of data where the high value of the standard deviation describes the distribution of data is high. Table 2 is a descriptive statistic chilli farmer households Kediri and Malang.

Table 2 shows seen income, gender, age, education, experience, family size, land use, land ownership status and household farmer groups who were respondents in this study have varying characteristics. The average income of respondents Rp.25.9 million per season with the lowest household income of Rp. 900,000 and the highest revenue of Rp 1 billion per season. Most of the chilli growers who were respondents in this study is a man. Selanjutnya male sex, the study respondents on average 47 years old. Where farmers youngest is 24 years old and a farmer who has the oldest age is 80 years. The level of education achieved by the respondent average is 9 years or at the level of secondary school (SMP). Some farmers do not take education and the highest level of education that is 14 years old. The experience farmers have on average 21 years old with 2 years of experience lows and highs of 60 years experience. The average member of the household of 23 people. Some farmers do not have household members and household members the highest 6 people. The land area used by farmers to plant chillies has an average area of $1900.343 \mathrm{~m} 2$ with $20 \mathrm{~m} 2$ of land which is the narrowest and widest $84800 \mathrm{~m} 2$. Land used by farmers to plant chillies is mostly proprietary. Furthermore, the respondents in this study largely participate in farmer groups.

Table 2: Descriptive Statistics

\begin{tabular}{|l|c|c|c|c|c|}
\hline \multicolumn{1}{|c|}{ Variable } & Obs & Mean & Std. Dev & Min & Max \\
\hline Income & 300 & 25900000 & 75100000 & 900000 & 1000000000 \\
\hline Gender & 300 & 1.013333 & 0.114889 & 1 & 2 \\
\hline Age & 300 & 47.46 & 11.40447 & 24 & 80 \\
\hline Education & 300 & 9.02027 & 3.769583 & 0 & 14 \\
\hline Experience & 300 & 21.86333 & 12.00019 & 2 & 60 \\
\hline number of Families & 300 & 2.57 & 1.078104 & 0 & 6 \\
\hline Land area & 300 & 1900.343 & 5066.276 & 20 & 84800 \\
\hline Land Status & 300 & 0.653333 & 0.476704 & 0 & 1 \\
\hline Farmers & 300 & 0.613333 & 0.4878 & 0 & 1 \\
\hline
\end{tabular}

\subsection{Comparative Characteristics of Households Based Financial Literacy Levels}

Table 3 is a comparison of the characteristics of the farmers who have a high level of financial literacy and financial literacy levels are low. To see the comparison between the two respondents serve targeted in this study using a different test average.

From the test results depending average age, education, family size, land area and participation in farmers' group had no significant difference between the farmer with a high level of financial literacy and farmers with low levels of financial literacy. Meanwhile, gender, experience, and status of land ownership did not differ significantly between the two 
groups of farmers. Farmers with high financial literacy levels have a lifespan and lower than the land area farmers with low literacy. While the education of farmers with high financial literacy education and the number of household members is higher than farmers with low financial literacy. Furthermore, farmers with high financial literacy more than the farmer groups participating in farmers with low financial literacy.

Table 3: Comparative Characteristics of Households Based Financial Literacy Levels

\begin{tabular}{|l|c|c|c|c|c|}
\hline \multirow{2}{*}{\multicolumn{1}{c|}{ Variables }} & \multicolumn{2}{|c|}{ Hight Financial Literacy $(\mathbf{n}=\mathbf{2 2 0})$} & Low Financial Literacy (n= 80) & \multirow{2}{*}{ t-Statistic } \\
\cline { 2 - 5 } & Mean & Std. Dev. & Mean & Std. Dev & 0077 \\
\hline Gender & 1.013636 & 0.1162404 & 1.0125 & 0.0125 & $0.1 .8717 *$ \\
\hline Age & 46.76364 & 11.73134 & 49375 & 10.2801 & $2.3455 * *$ \\
\hline Education & 9.286364 & 3.224449 & 7.8375 & 5.171597 & -0.0414 \\
\hline Experience & 21.84545 & 11.79442 & 21.9125 & 12.62526 & $2.5634 * *$ \\
\hline number of Families & 2.668182 & 1.048542 & 2.3 & 1.118317 & $-1.1923 *$ \\
\hline Land area & 1561.059 & 1418.259 & 2833.375 & 9506.161 & 1.6308 \\
\hline land status & 0.6272727 & 0.4846331 & 0725 & 0.449331 & $2.9191 * * *$ \\
\hline Farmers & 0.6636364 & 0.4735424 & 0475 & 0.502525 & 2.917 \\
\hline
\end{tabular}

Note: $* * *, * * *$ indicates significant at each level of $10 \%, 5 \%$ and $1 \%$.

\subsection{Respondent Characteristics Influence on Financial Literacy Level Farmers Cabe}

Logit regression analysis is one of the stages of the analysis of propensity score matching. Logit regression is required to obtain propensity score (p-score) from each of the respondents in the study. P-score is then used as a reference for comparing the output of each respondent. On the other hand, logit regression analysis can also be used to determine the effect of the characteristics of households on their financial literacy. Logit regression analysis showed farmers age, education level, family size and participation in farmers' group has a significant influence on the level of financial literacy of farmers. Meanwhile, gender, experience, area of land and land ststus not statistically significant effect on the level of financial literacy of farmers.

Age a significant negative effect on the chances of farmers to have financial literacy tinggi.Artinya, the higher the age of the farmer then their chances to have a high financial literacy is getting low. This finding is contrary to the results of research conducted by (Taft et al., 2013; Hassan \& Anood 2009). The inconsistency of these results with other studies due to differences in the characteristics of households to be sampled. Suppose if we see from the level of education and age, they have a negative correlation. This means that the older the respondent then taken by the lower education. In fact, education is one of the sources for a person to boost their knowledge of one of them is financial knowledge.

Education variable coefficient is positive and significant at the level of 5\%.This shows that education has a positive and significant impact on the chances of farmers to financial literacy memimiliki tinggi.artinya, the higher education of farmers then their chances to have financial literacy tinggipun will increase. This finding is not surprising where education is a source of knowledge for everyone wrong astunya found financial knowledge is in line with (Hassan \& Anood 2009; Bhushan \& Medury, 2013).

Number of family members has a positive and significant impact on the chances of farmers to have financial literacy frequency. This shows the greater number of members of the family then the chances of farmers to have a high financial literacy will be higher as well. This finding is consistent with (Jappelli\& Padula, 2013).Finally, the participation of farmers in farmer groups and significant positive effect on their chances to have financial literacy tinggi.Artinya, farmers participating in farmer groups have a higher chance to have a high financial literacy dibandi 
farmers who did not participate in the group. Several studies have shown that kelompoktani the social capital that can increase farmers' access to information that they need (Kassie et al., 2013) one of them is financial related information.

Table 4: Respondent Characteristics Influence on Financial Literacy Level Farmers Cabe

\begin{tabular}{|l|c|c|c|c|}
\hline \multicolumn{1}{|c|}{ Financial Literacy } & Coef. & Std. Err & $\mathbf{Z}$ & $\mathbf{P}>\mid \mathbf{z}$ \\
\hline Gender & 0.379959 & 0.749935 & 0.51 & 0612 \\
\hline Age & -0.02284 & 0.009543 & -2.39 & $0017 * *$ \\
\hline Education & 0.06336 & 0.021908 & 2.89 & $0004 * * *$ \\
\hline Experience & 0.013548 & 0.008831 & $1: 53$ & 0125 \\
\hline number of Families & 0.176237 & 0.07755 & $2: 27$ & $0023 * *$ \\
\hline Land area & $-4.6 \mathrm{E}-05$ & 0.000045 & -1.02 & 0309 \\
\hline land status & -0.26264 & 0.1804 & -1.46 & 0145 \\
\hline Farmers & 0.5529 & 0.170424 & $3: 24$ & $0001 * * *$ \\
\hline cons & -0.01708 & 0.94687 & -0.02 & 0986 \\
\hline Log likelihood $=-152.97221$ & & & & \\
\hline Number of obs $=300$ & & & & \\
\hline LR chi2 $(8)=35.46$ & & & & \\
\hline Prob> chi2 $=0.0000$ & & & & \\
\hline Pseudo R2 $=0.1039$ & & & & \\
\hline
\end{tabular}

Note: $*, * *, * * *$ indicates significant at each level of $10 \%, 5 \%$ and $1 \%$.

\subsection{Impact Analysis of Financial Literacy on the Adoption Credit}

Analysis of the impact of literacy on the adoption of the loan using probit model shows that each of the predictor variables have a significant influence on the adoption credit. At the significant level of $1 \%$, the farmer group variable influence on the rate of adoption of credit. At the 5\% significance level, financial literacy variables, age, and education influence the rate of adoption of credit. While the significant level of $10 \%$, a variable experience, family size, land use, and land status give effect to the adoption credit.

The relationship of each predictor variable to variable credit adoption is divided into positive and negative relationships. According to the data attached, was positively related to the adoption of variable credit occurred in variable financial literacy, education, experience, and the number of families. While the negative correlation to variable credit adoption happening in age, land, land status, and farmer groups.

Positive relationships are owned by the adoption of the financial literacy variable credit means that the higher the person's knowledge in financial managerial would allow adopting credit products of financial institutions. This is consistent with the statement Lusardi (2008) which states that financial education will push up savings and improve the quality of decision making in the field of finance.

The negative relationship between age owned by the adoption of credit means that the person's age will decrease the chances of someone accessing credit products of a financial institution. This is supported by research Supardi (2004) which stated that in general people are getting older productivity will decrease. Even one day no longer productive, but still consumptive. Therefore, when he was young people have started saving in various forms of backup older on the day, so as not to become a burden to others.

Negative relationship status variable land owned by the adoption of credit means that when a farmer's status as a sharecropper will reduce the possibility for him to use credit products of a financial institution, the condition is caused by the lack of guarantee that may be required to the financial institution. Backed by J. \& Hiola Sumarno statement FS I (2000) 
which states that in general people get older productivity will decrease. Even one day no longer productive, but still consumptive. Therefore, when he was young people have started saving in various forms of backup older on the day, so as not to become a burden to others.

Table 5: Impact of the Adoption Credit Financial Literacy Farmers Cabe

\begin{tabular}{|c|c|c|c|c|}
\hline Adoption Credit & Coef. & Std. Err & $\mathbf{z}$ & $\mathbf{P}>|\mathbf{z}|$ \\
\hline Financial Literacy & 0.01652 & 0.006747 & $2: 45$ & $0014 * *$ \\
\hline Age & -0.02203 & 0.010225 & -2.15 & $0031 * *$ \\
\hline Education & 0.052014 & 0.022253 & $2: 34$ & $0019 * *$ \\
\hline Experience & 0.002427 & 0.008561 & $0: 28$ & 0777 \\
\hline number of Families & 0.030478 & 0.075127 & $0: 41$ & 0685 \\
\hline Land area & -0.00004 & $4.33 \mathrm{E}-05$ & -0.93 & 0355 \\
\hline land status & -0.12494 & 0.169713 & -0.74 & 0462 \\
\hline Farmers & -0.49113 & 0.169544 & -2.9 & $0004 * * *$ \\
\hline _cons & 0.499215 & 0.654293 & 0.76 & 0445 \\
\hline corr (e.fl, e.kredit) | & -0.25093 & 0.189688 & & \\
\hline sd (e.fl)| & 24.8781 & 1.015644 & & \\
\hline \multicolumn{5}{|c|}{ Log likelihood $=-1557.5185$} \\
\hline \multicolumn{5}{|l|}{ Number of obs $=300$} \\
\hline Wald chi2 $(8)=46.37$ & & & & \\
\hline Prob $>$ chi $2=0.0000$ & & & & \\
\hline
\end{tabular}

Note: *,***** indicates significant at each level of $10 \%, 5 \%$ and $1 \%$.

\subsection{Financial Literacy Impact on Farmers Income}

Propensity Score Matching (PSM) in this study are used to estimate the impact of the financial literacy level of farmers' income to chillies in Kediri and Malang. The results of the propensity score matching analysis can be seen in Table 6.

Measuring the impact of the level of financial literacy with PSM, this study used four matching method comprising; nearest neighbor matching (NNM), radius matching, karnel matching and stratification method. Table 6 illustrates the impact of the financial literacy levels of the chili farmers' income by 4 the matching method. NNM produce matching results showed Average Treatment Effect on the Treated (ATT) amounted to 25.3 million, matching the radius of 24300000, 24500000 and by matching karnel stratification method as big as 24700000 . Further views of significance acquired, fourth matching method has significance at the level of $1 \%$. These results indicate that the high level of financial literacy and significant positive impact on farmers' income. In comparison, farmers with high financial literacy levels have higher revenue of Rp. to \$24.3 million. 25.3 million Compared to farmers with low levels of financial literacy.

Figure 1 shows this finding is consistent with previous studies (Braunstein and Welch, 2002; Jacob, Hudson, and Bush, 2000; Servon and Kaestner, 2008) they argue that a person's low-income people tend to have low levels of financial literacy,Furthermore, (Webster and Fidler, 1996; Chelcea 2002) Explains that most low-income people very berhantung to informally with high interest rates. As collateral, farmers are required to sell their products to the informal institutions with low price. On the other hand (Lusardi and Tufano, 2009) suggest that individuals with low levels of financial literacy have difficulty in managing their finances, one of the difficulties in restoring debt, This is what makes the farmers can not be separated from the informal financial institutions. 
Table 6: Financial Literacy Impact on Farmers Income Cabe

\begin{tabular}{|l|c|c|c|c|c|}
\hline \multicolumn{1}{|c|}{ Matching Method } & Treatment & Control & ATT & Std. Err & T \\
\hline NNM & 218 & 57 & 25300000 & 7560000 & $3353 * * *$ \\
\hline radius Matching & 218 & 71 & 24300000 & 4630000 & $5246 * * *$ \\
\hline kernel Matching & 218 & 71 & 24500000 & 4660000 & $5251 * * *$ \\
\hline stratification method & 218 & 71 & 24700000 & 10600000 & $2342 * * *$ \\
\hline
\end{tabular}

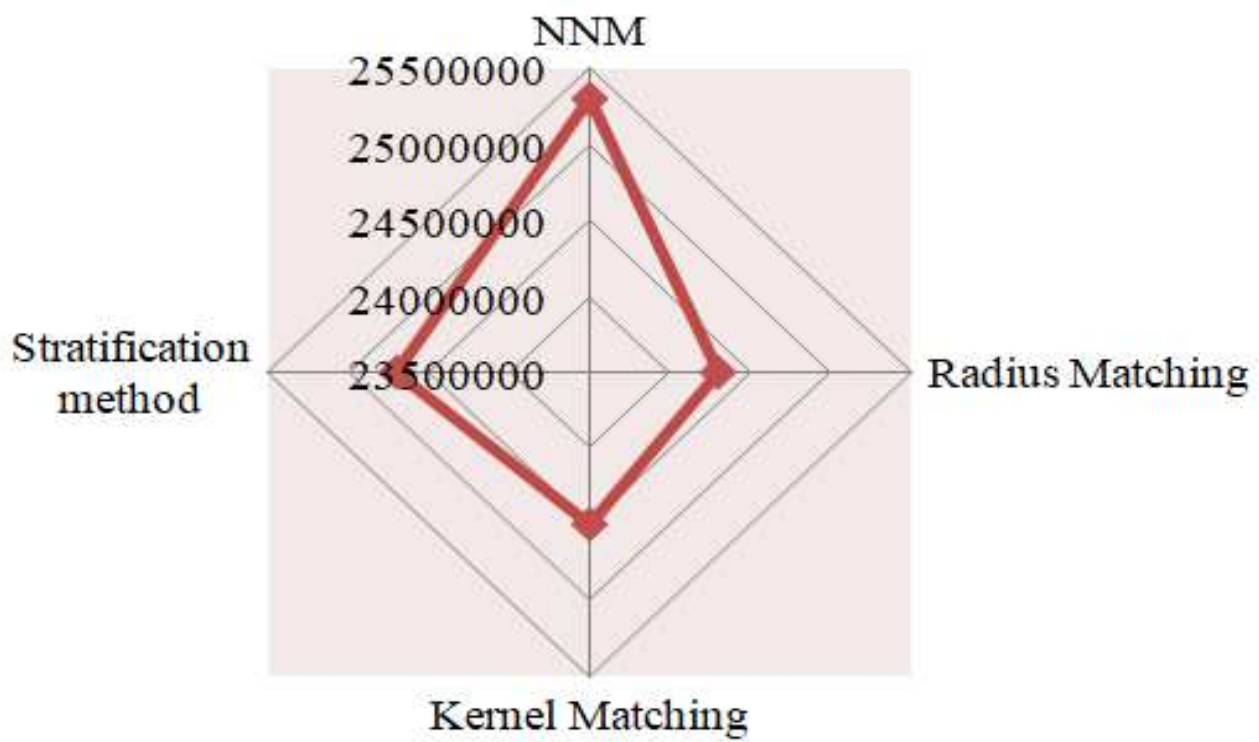

Figure 1: Financial Literacy Impact on Farmers Income Cabe.

\section{CONCLUSIONS}

From the research that has been done, it can be summarized as follows; factors are positive and significant impact on the level of financial literacy namely education level, family size and participation in farmers' groups. While age negatively affect farmers' level of financial literacy. Furthermore, financial literacy has an important role to the adoption of the decision of credit and welfare of farmers. With a high level of financial literacy cederung farmers can make good decisions in financial matters. Based on the results of financial literacy have an impact in the adoption credit. The ability of chilli growers in the adoption credit in line with its impact on the welfare of farmers chili.

The results, at least, provide valuable information. One is the effort to improve financial literacy among small farmers to be followed by participation in farmer groups. Without this effort, participation may be lower farmers, and farmers who already have a good level of financial literacy, credit may not adopt. One effort that might be done is to provide knowledge about financial literacy through farmer groups.

\section{REFERENCES}

1. Afrin, S., Haider, MZ, and Islam, MS (2017). Impact of financial inclusion on technical efficiency of paddy farmers in Bangladesh. Agricultural Finance Review, 77 (4), 484-505. doi: 10.1108 / AFR-06-2016-0058.

2. Agarwal, S., Amromin, G., Ben-David, I., Chomsisengphet, S., \& Evanoff, DD (2015). Financial literacy and financial planning: Evidence from India. Journal of Housing Economics, 27, 4-21. doi: 10.1016/j.jhe.2015.02.003.

3. Ajah, EA, Igiri, JA, \& Ekpenyong, HB (2018).Determinants of access to credit among rice farmers in Biase Local Government Area of Cross River State, Nigeria.Global Journal of Agricultural Sciences, 16 (1), 41. doi : 10.4314 / gjass.v16i1.6.

4. Ajani, A. K. I. N. L. O. L. U., and BAKARE OLALEKAN Olanrewaju. "Avocado pear fruits and leaves aqueous extracts inhibit 
$\alpha$-amylase, $\alpha$-glucosidase and snp induced lipid peroxidation-an insight into mechanisms involve in management of type 2 diabetes." Int J Appl Nat Sci 3 (2014): 2134.

5. Akoijam, SLS (2012). Rural credit: a source of sustainable livelihood of rural India. International Journal of Social Economics, 40 (1), 83-97. doi: 10.1108/03068291311283454.

6. Arkam, W., Haussain, Z., Damn, MH, Hussain I. (2008). Agricultural credit constraints and borrowing behavior of farmers in Rural Punjab. European Journal of Scientific Research ISSN 1450-216X Vol.23 No.2 (2008), pp.294304.

7. Arora, RU, (2014). "Access to Finance: An Empirical Analysis," The European Journal of Development Research, Palgrave Macmillan; European Association of Development Research and Training Institutes (EADI), vol. 26 (5), pages 798-814, December.

8. Bank Indonesia. (2014), The Experience and Evaluation of Financial Education in Indonesia. Directorate of Banking Research and Regulation. Jakarta, Indonesia: [BI] Bank Indonesia.

9. Bayrakdaroğlu, A., \& San, FB (2014).Financial Literacy Training as a Strategic Management Tool among Small - Medium Sized Businesses Operating in Turkey. Procedia - Social and Behavioral Sciences, 150, 148-155. doi: 10.1016 / j.sbspro.2014.09.019.

10. Beck, T., Demirgüç-Kunt, A., and Martinez Peria, MS (2008). Banking Services for Everyone? Barriers to Bank Access and Use around the World. The World Bank Economic Review, 22 (3), 397-430. doi: 10.1093 / wber / lhn020.

11. Carman, GK, and Zamarro, G. (2016). Financial Literacy does Contribute to Food Security? International Journal of Food Agriculture Econmics. January 2016; 4 (1): 119.

12. Cole, S., Sampson. T., Zia, B. (2009). Financial Literacy, Financial Decisions, and the Demand for Financial Services: Evidence from India and Indonesia. Working Paper 09-117. Harvard Business School.

13. Filipiak, U. (2016). Trusting financial institutions: Out of reach, out of trust? The Quarterly Review of Economics and Finance, 59, 200-214. doi: 10.1016/j.qref.2015.06.006.

14. García-Herrero, A., Gavila, S., Santabarbara, D. (2009). What Explains the low profitability of Chinese banks ?. Journal of Banking and Finance 33 (11), 2080-2092.

15. Grohmann, A. (2017). Financial Literacy and Financial Behavior: Evidence from the Emerging Asian Middle Class. SSRN Electronic Journal. doi: 10.2139 / ssrn.3084021.

16. Judge, MS, Oktavianti, V., \& Gunarta, IK (2018). Determining Factors That Contribute to Financial Literacy for Small and Medium Enterprises. IOP Conference Series: Materials Science and Engineering, 337, 012064. doi: 10.1088/ $1757-899 x / 337 / 1 / 012064$.

17. Hilgert, MA, Hogarth, JM, and Beverly, GS (2003). Household financial management: the connection between knowledge and behavior. Federal Reserve Bulletin, 2003, issue July, 309322.

18. Huston, SJ (2009). Measuring Financial Literacy. SSRN Electronic Journal. doi: 10.2139 / ssrn.1945216.

19. Jang, K., Hahn, J., \& Park, HJ (2014).Comparison of financial literacy between Korean and US high school students. International Review of Economics Education, 16, 22-38. doi: 10.1016/j.iree.2014.07.003.

20. Kefela, GT, (2010). Promoting access to finance by empowering consumers - Financial literacy in developing countries. Educational Research and Reviews Vol. 5 (5), pp. 205212.

21. Klapper, L., Lusardi, A., \& Panos, GA (2013). Financial literacy and its consequences: Evidence from Russia during the financial crisis. Journal of Banking \& Finance, 37 (10), 3904-3923. doi: 10.1016/j.jbankfin.2013.07.014. 
22. Lusardi, A., \& Mitchell, O. (2011). Financial Literacy around the World: An Overview. doi: 10.3386/w17107.

23. Lusardi, A., \& Mitchell, OS (2007). Financial Literacy and Retirement Planning: New Evidence from the Rand American Life Panel. SSRN Electronic Journal. doi: 10.2139 / ssrn.1095869.

24. Lusardi, A., \& Tufano, P. (2009).Debt Literacy, Financial Experiences, and Overindebtedness.doi: $10.3386 /$ w14808.

25. Lusardi, A., 2012. Numeracy, Financial Literacy, and Financial Decision-Making.Numeracy, 5 (1). Available at: http://dx.doi.org/10.5038/1936-4660.5.1.2.

26. Mabula, JB, \& Dong, H. (2018). Financial Literacy of SME Managers' on Access to Finance and Performance: The mediating Role of Financial Service Utilization. International Journal of Advanced Computer Science and Applications, 9 (9). doi: 10.14569 / ijacsa.2018.090905.

27. Malangmeih, L., and S. M. Rahaman. "Economics of fresh Naga King chilli in Manipur, India-a case study." International Journal Environment, Ecology 6 (2016): 151162.

28. Oanea, D.-C., \& Dornean, A. (2012). Defining and Measuring Financial Literacy. New Evidence from Romanian 'Students of the Master in Finance.Annals of the Alexandru Ioan Cuza University - Economics, 59 (2).doi: 10.2478 / v10316-012-0036-3.

29. Orientation of Financial Services, the 2018 National Survey of Financial Inquisition 2018.Index Litersi and Financial Literacy Indonesia.

30. Patel, JISNU K., K. S. Jadav, and H. C. Parmar. "An analysis of resource use efficiency of drip and conventional chilli farm in middle Gujarat." International Journal of Humanities and Social Sciences, 3 (3), 8591 (2014).

31. Patel, V. K., S. P. Gupta, and K. L. Patel."Economics performance of chilli (Capsicum annuum L.)cultivation in Raigarh district of Chhattisgarh state." International Journal of Agricultural Science and Research (IJASR) 5.4 (2015): 363368.

32. Rahut, DB, Velásquez Castellanos, I., \& Sahoo, P. (2012). Performance of financial institutions in Bhutan. Asia-Pacific Development Journal, 19 (1), 97-138. doi: 10.18356 / 6a15f76c-en.

33. Robb, Cliff A. and Woodyard, Ann, (2011).Financial Knowledge and Best Practice Behavior.Journal of Financial Counseling and Planning, Vol. 22, No. 1, 2011.

34. Servon, LJ \& Kaestner, R., 2008.Consumer Financial Literacy and the Impact of Online Banking on the Financial Behavior of Lower-Income Bank Customers.Journal of Consumer Affairs, 42 (2), pp.271-305. Available at: http://dx.doi.org/10.1111/j.1745-6606.2008.00108.x.

35. Shahidur Khandker Gayatri R. B. Koolwal Hussain A. Samad. 2010. Handbook on Impact Evaluation of Quantitative Methods and Practices. Learning.Vol. 1.

36. Sreelakshmi, CC (2017). Impact of the Financial Literacy Program on Farmers in Pullu Village. International Journal of Research in Humanities, Arts and Literature (IMPACT: IJRHAL) Vol. 5, Issue 10, 1118.

37. Travnichek, J., R. (2008). Delivering Financial Literacy Instruction to Adults. Journal of Financial Counseling and Planning; Columbus Vol. 19, Iss. 2.

38. Wachira, MI \& Kihiu, EN (2012).Impact of Financial Literacy on Access to Financial Services in Kenya. International Journal of Business and Social Science Vol. 3 No. 19.

39. Widhiyanto, I. Nuryartono, N. Harianto, H. Siregar H. (2018). The Analysis of Farmers 'Financial Literacy and its' Impact on the Accessibility of Microcredit with the Interest Subsidy on Agricultural Sector. International Journal of Economics and Financial Issues, 2018, 8 (3), 148159. 
40. Woodyard, A., \& Robb, C. (2012).Financial Knowledge and the Gender Gap.Journal of Financial Therapy, 3 (1) 1. https://doi.org/10.4148/jft.v3i1.1453. 